\title{
Zooplankton feeding ecology: contents of fecal pellets of the appendicularian Oikopleura vanhoeffeni
}

\author{
Don Deibel ${ }^{1 *} \&$ Jefferson T. Turner ${ }^{2}$ \\ ${ }^{1}$ Marine Sciences Research Laboratory, and Newfoundland Institute for Cold Ocean Science, Memorial University of \\ Newfoundland, St. John's, Newfoundland A1C 5S7, Canada \\ ${ }^{2}$ Biology Department, Southeastern Massachusetts University, North Dartmouth, Massachusetts 02747, USA
}

\begin{abstract}
Using scanning electron microscopy, we examined the undigested contents of fecal pellets from hand-collected Oikopleura vanhoeffeni Lohmann. Our goals were to compare the size of food in fecal pellets to the pore size of the incurrent filters, and to compare the size and type of food in fecal pellets to the size and type of food available in the environment. We collected $O$. vanhoeffeni in coastal waters of Newfoundland in May 1983, during the spring diatom bloom, and in January 1984. when diatoms were rare. Because the pore size of the incurrent filters was large $(\bar{X}=169 \times 88 \mu \mathrm{m}), O$. vanhoeffeni was able to ingest the large, armored cells and diatom chains present during the spring bloom. The largest cells in fecal pellets were smaller than the mean pore width of the incurrent filters. The largest single cell in fecal pellets was the silicoflagellate Distephanus speculum $(48 \mu \mathrm{m}$ in diameter). Many tabular chains of pennate diatoms in fecal pellets were $>40 \mu \mathrm{m}$ long. Spinous Chaetoceros socialis were ingested. In January, the fecal pellet contents were dominated by coccoliths along with common dinoflagellates and diatoms. Each fecal pellet was surrounded by a peritrophic membrane.
\end{abstract}

\section{INTRODUCTION}

Appendicularia are gelatinous, transparent zooplankters that use external and internal mucous nets to feed on a wide size range of suspended particles (Alldredge 1977, 1981). The complex apparatus containing the external mucous nets is known as the 'house'. Oikopleuridae is a group of appendicularians of cosmopolitan distribution that is abundant in neritic waters. Feeding mechanism and behavior of Oikopleuridae have been described in general and will not be reviewed here (Alldredge 1977, Alldredge \& Madin 1982). Most oikopleurids draw water into the house through a pair of coarse, incurrent mucous filters (an exception is Oikopleura longicauda which has no incurrent filters: Alldredge 1977). The pore size of the incurrent filters determines the upper size limit of food particles available for ingestion (Alldredge 1975).

Since the pioneering work of Lohmann (1909), it has been accepted that the Oikopleuridae ingest primarily

\footnotetext{
- Order of authors is alphabetical
}

ultraplankton $<3 \mu \mathrm{m}$ in diameter and nanoplankton 3 to $20 \mu \mathrm{m}$ in diameter. Reports of the diet of oikopleurids rarely include the description of net-phytoplankton $>20 \mu \mathrm{m}$ in diameter. The few large cells that have been reported were found in lower proportion in fecal pellets than in the environment (Alldredge 1975, Jansa 1977). Chain-forming or spinous cells were excluded by the incurrent filters (Lohmann 1909, Alldredge 1977). However, these observations were of oikopleurids of small and medium body size from tropical and temperate waters. We know little of the diets of larger oikopleurids, and nothing of the diet of the large, abundant, cold ocean oikopleurid Oikopleura vanhoeffeni. Given the size of $O$. vanhoeffeni (adult trunk length 4 to $7 \mathrm{~mm}$ ), and the pore size of its incurrent filters $(\overline{\mathrm{X}}=169 \times 88 \mu \mathrm{m})$, it is likely that the size composition of its diet differs from that of the smaller, well-studied $O$. dioica (adult trunk length of 0.8 to $1.0 \mathrm{~mm}$ ), with an incurrent filter pore width of 20 to $25 \mu \mathrm{m}$ (Galt 1972).

Physiological information on Oikopleura vanhoeffeni is lacking even though it is one of the dominant 
zooplankters of coastal Newfoundland waters (Udvardy 1954). During the spring diatom bloom of 1983 (Apr-May), we discovered large, intact pennate diatoms in fecal pellets of hand-collected $O$. vanhoeffeni. We used the scanning electron microscope (SEM) to investigate the undigested contents of fecal pellets of $O$. vanhoeffeni, both during the spring diatom bloom and in mid-winter during flagellate dominance. Our goals were: (1) to compare the size of phytoplankton in fecal pellets to the pore width of the incurrent filters, and (2) to compare semi-quantitatively the size and species composition of phytoplankton in fecal pellets to phytoplankton available in the environment. This approach has been used successfully to observe the feeding habits of both gelatinous and crustacean zooplankton (Silver \& Bruland 1981, Turner 1984a-c). There has been only one study of oikopleurid feeding that compared ingested phytoplankton to phytoplankton available in the environment (Alldredge 1975). There was no statistically significant difference in the size of the largest food particle on the feeding filter, in the gut, or in fecal pellets (Alldredge 1975). Therefore, we decided to examine the contents of fecal pellets.

\section{MATERIAL AND METHODS}

We collected Oikopleura vanhoeffeni in $400 \mathrm{ml}$ glass jars by hand using SCUBA. Appendicularians were collected in Logy Bay, Newfoundland, in water depths of 5 to $15 \mathrm{~m}$. At the same time and depth, $10 \mathrm{l}$ water samples were taken, from which duplicate subsamples $(125 \mathrm{ml})$ were drawn to be fixed with Utermöhl's iodine for phytoplankton cell counts (Utermöhl 1958). Two collections were made during the spring diatom bloom ( 2 and 6 May, 1983), and one collection was made in mid-winter when diatoms were rare (24 January, 1984). Water temperature was $0.6{ }^{\circ} \mathrm{C}$ in May and $-1.1^{\circ} \mathrm{C}$ in January. Salinity was $31.5 \%$ in January, which is typical of Logy Bay throughout the year (Kendaris 1980). Appendicularians and houses were not fixed in the field because we wished to first measure live individuals, and unfixed houses and fecal pellets.

Jars containing appendicularians were placed in a flow-through seawater bath in the laboratory within 30 min of collection. Water temperature in the bath was 1.0 to $2.0 \mathrm{C}^{\circ}$ higher than that at the depth of collection. Over the next $12 \mathrm{~h}$ appendicularians and houses were removed from each jar to collect fecal pellets. Many of the individuals were still feeding in the house in which they were collected. However, a few specimens had made as many as 3 houses since collection. Because the house of Oikopleura vanhoeffeni shrinks and becomes opaque quickly after being abandoned ( 1 to 2 h), it was possible to rank the houses in a jar in chronological order. Since fecal pellets remain trapped within the house, it was possible to determine the relative ages of fecal pellets in each jar. We found no qualitative difference in the contents of fecal pellets between the house in which the appendicularian was collected and houses produced in the laboratory for up to $12 \mathrm{~h}$ after collection.

Houses were teased apart with fine-tipped forceps, and fecal pellets collected individually with a Pasteur pipette. Each fecal pellet was either fixed immediately in $5 \%$ borate buffered formaldehyde in filtered seawater $(0.8 \mu \mathrm{m}$ membrane), or was aged in filtered seawater at room temperature for 36 to $48 \mathrm{~h}$ before fixing so that bacteria could decompose the membrane surrounding the pellet. Using a stereomicroscope with ocular micrometer, fecal pellet length and width was measured to the nearest $12.5 \mu \mathrm{m}$, and trunk length, from mouth to the posterior margin of the stomach, and tail length was measured to the nearest $25 \mu \mathrm{m}$. The pore length and width of the incurrent filters was measured to the nearest $7.5 \mu \mathrm{m}$, using a compound microscope with phase contrast and ocular micrometer.

Fixed pellets for SEM examination were placed individually in filtered seawater, and were drawn onto Whatman GF/C glass fiber filters. Filters with attached fecal pellets were immersed in distilled water to eliminate salt, dehydrated in a graded ethanol series, critical-point dried, coated with gold:palladium, and examined with an ISI-30 SEM at $15 \mathrm{kV}$ (Turner $1984 a-c)$. Entire visible sides of fecal pellets were examined and recognizable contents were photographed. The 31 micrographs presented here $(25 \%$ of those taken) are representative of fecal pellet contents on all sampling dates.

Duplicate $50 \mathrm{ml}$ subsamples of sea water were settled for a minimum of $24 \mathrm{~h}$ for inverted microscope counts of available food particles (phase contrast). Small cells $(<30 \mu \mathrm{m})$ were measured at $500 \times$ magnification to the nearest $0.5 \mu \mathrm{m}$. Sufficient $1 \mathrm{~cm}$ transects were made until at least 30 individuals of the 3 dominant taxa were counted, resulting in a $95 \%$ confidence interval of $\pm 30 \%$ of the count (Lund et al. 1958). Large cells were measured at $125 \times$ magnification to the nearest $1.9 \mu \mathrm{m}$. One-half of the chamber was covered in counting large cells (subsample volume of $25 \mathrm{ml}$ ). Small cells $(<5 \mu \mathrm{m})$ that appeared featureless were classified as unidentified unicells, and all other small cells that appeared featureless but seemed to contain chloroplasts were classified as unidentified naked flagellates and monads. Dominant diatoms and dinoflagellates were identified to genus and species when possible. Cell volume was calculated by approximating cell shape to that of simple geometric solids (e.g. right cylinder, prolate spheroid, sphere). 


\section{RESULTS}

\section{Available phytoplankton cells}

Unicells $<1.5 \mu \mathrm{m}$ in diameter comprised 35 to $90 \%$ of total cell number in all samples. Because of difficulty identifying these cells, and because of their small contribution to cell volume, they were not included in plots of frequency distribution of cell type and size (Fig. $1 \& 2$ ).

There was a marked difference in the composition and size frequency distribution of phytoplankton cells between May and January. On 2 May, the samples were dominated by small pennate diatoms which formed long tabular chains (Fig. 1). These pennate diatoms had a mean cell length of $19 \mu \mathrm{m}$ (Table 1); they were primarily Nitzschia grunowii Hasle and N. cylindrus (Grunow) Hasle. On 6 May cell volume was dominated by the solitary pennate diatom Nitzschia sp. (Fig, 1) because of its larger mean size (32 $\times 7 \mu \mathrm{m}$ : Table 1). On both days the subdominant component of cell volume was the large centric diatom Thalassiosira sp. which was 25 to $29 \mu \mathrm{m}$ in diameter (Fig. 1; Table 1). Total cell concentration and volume was similar on both sampling days in May (Table 1). In all samples collected in May diatoms made up 63 to $83 \%$ of total cell number (excluding small unicells), and 81 to $98 \%$ of total cell volume.

In January samples were numerically dominated (99\% of total number) by small monads and flagellates (Fig. 1) about $3 \mu \mathrm{m}$ in diameter (Table 1). Cell volume

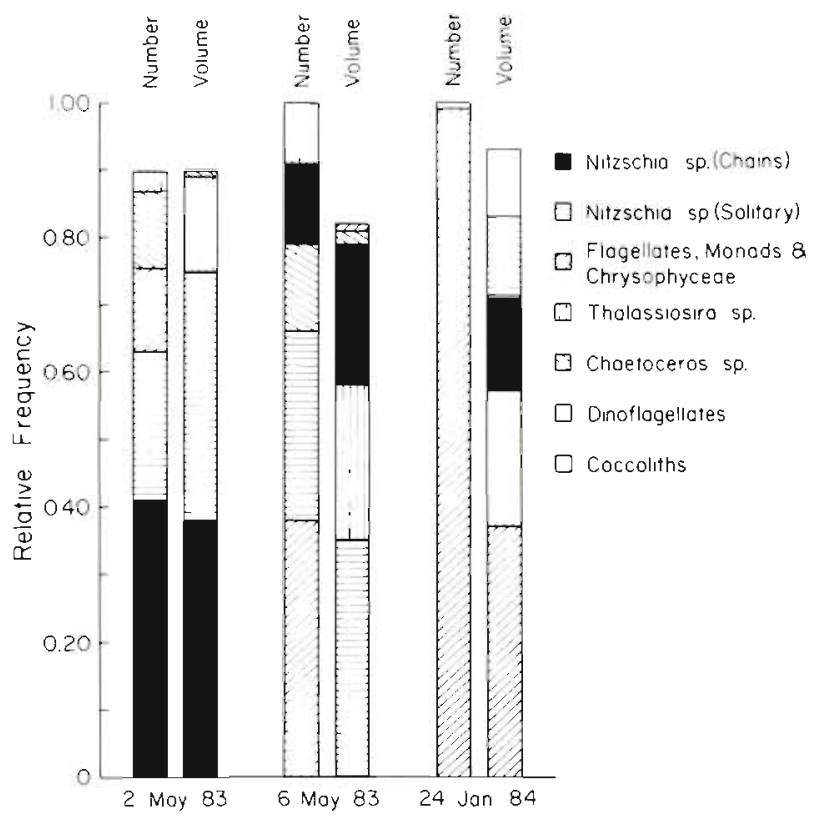

Fig. 1. Relative frequency ( $\%$ of total number and volume) of the dominant phytoplankton taxa available for food of Oikopleura vanhoeffeni on 3 sampling dates
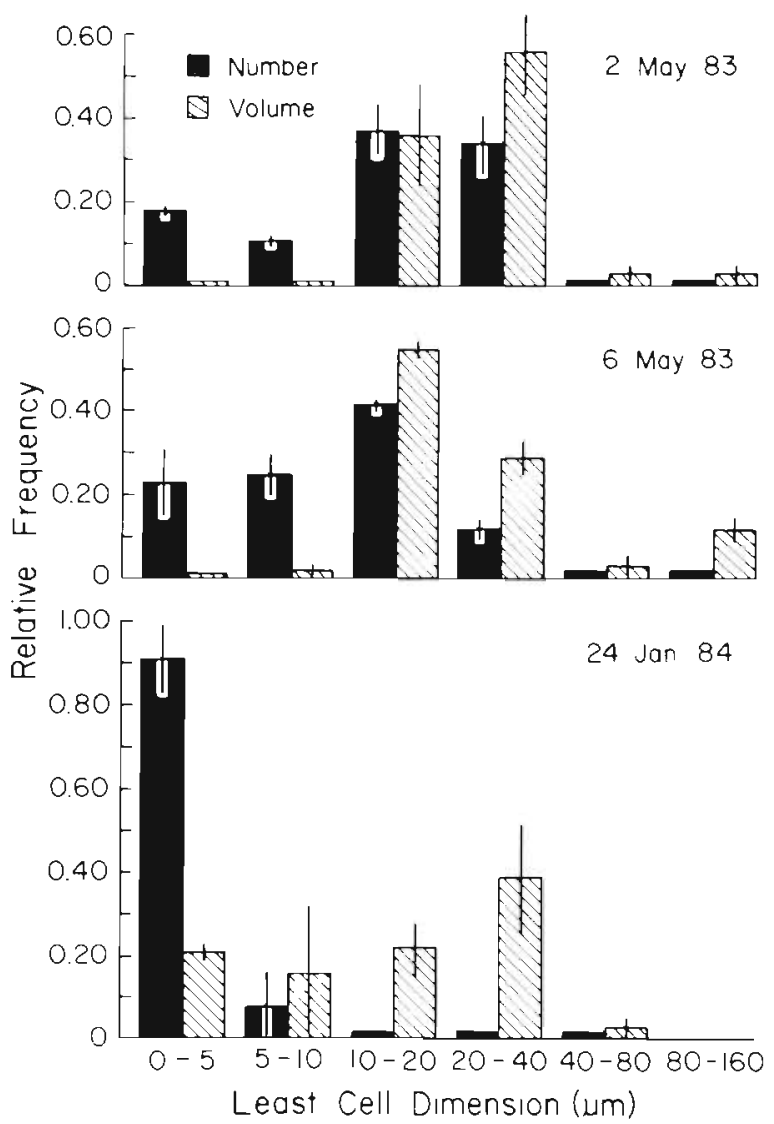

Fig. 2. Relative frequency of all phytoplankton taxa available for food of Oikopleura vanhoeffeni in 6 size classes from 0 to 5 to 80 to $160 \mu \mathrm{m}$ least cell dimension (i.e. width or diameter).

Vertical lines represent range of duplicate cell counts

was dominated (39\% of total volume) by larger flagellates and Chrysophyceae (Fig. 1), $5 \mu \mathrm{m}$ in diameter (Table 1). Unarmored dinoflagellates made a codominant contribution to cell volume (Fig. 1). Nitzschia grunowii and $N$. cylindrus were rare, but the solitary Nitzschia sp. had a larger cell size than in May (36 $\mu \mathrm{m}$ long: Table 1), and so diatoms made up $30 \%$ of total cell volume (chains + solitary cells: Fig. 1). Total cell concentration was much higher than in May because of the dominance of flagellates, but total cell volume was an order of magnitude lower (Table 1).

Small, spinous Chaetoceros sp. were common on 2 and 6 May (Fig. 1), while the large pennate diatom Rhizosolenia sp. was found in concentrations of 2 to 3 $\mathrm{ml}^{-1}$ on both days, comprising 2 to $15 \%$ of total cell volume. There were no coccolith plates or whole coccolithophores in any of the samples from May.

In January dinoflagellates were only slightly more concentrated than in May (4 to $11 \mathrm{ml}^{-1}$ ), but they comprised $29 \%$ of total cell volume because of the paucity of diatoms ( 7 to $14 \mathrm{ml}^{-1}$ ). There were no Rhizosolenia sp. or Chaetoceros sp. present in January. However, there were some large pennate diatoms 
Table 1. Dominant available food items for Oikopleura vanhoeffeni on 3 sampling dates

\begin{tabular}{|c|c|c|c|c|c|c|}
\hline Date & Dominant taxon & $\begin{array}{c}\text { Cell } \\
\text { length } \\
(\mu \mathrm{m})\end{array}$ & $\begin{array}{l}\text { Cell } \\
\text { width } \\
(\mu \mathrm{m})\end{array}$ & $\begin{array}{c}\text { Cell } \\
\text { diameter } \\
(\mu \mathrm{m})\end{array}$ & $\begin{array}{l}\text { Total cell } \\
\text { concentration } \\
\text { (No. } \mathrm{ml}^{-1} \text { ) }\end{array}$ & $\begin{array}{l}\text { Total cell } \\
\text { volume } \\
\left(\mu \mathrm{m}^{3} \mathrm{ml}^{-1}\right)\end{array}$ \\
\hline \multirow[t]{6}{*}{2 May 1983} & $\begin{array}{l}\text { Nitzschia sp. } \\
\text { (chains) }\end{array}$ & 19 & 7 & - & & \\
\hline & $\begin{array}{l}\text { Nitzschia sp. } \\
\text { (solitary) }\end{array}$ & 27 & 7 & - & & \\
\hline & Thalassiosira sp. & - & - & 29 & & \\
\hline & Chaetoceros sp. & - & - & 7 & & \\
\hline & $\begin{array}{l}\text { Unid. flagellates } \\
\text { and monads }\end{array}$ & - & - & 3 & & \\
\hline & & & & & 1983 & $6.0 \times 10^{6}$ \\
\hline \multirow[t]{7}{*}{6 May 1983} & $\begin{array}{l}\text { Nitzschia sp. } \\
\text { (chains) }\end{array}$ & 19 & 7 & - & & \\
\hline & $\begin{array}{l}\text { Nitzschia sp. } \\
\text { (solitary) }\end{array}$ & 32 & 7 & - & & \\
\hline & Thalassiosira sp. & - & - & 25 & & \\
\hline & Chaetoceros sp. & - & - & 7 & & \\
\hline & $\begin{array}{l}\text { Unid. flagellates } \\
\text { and monads }\end{array}$ & - & - & 4 & & \\
\hline & $\begin{array}{l}\text { Unid. large } \\
\text { flagellates and } \\
\text { Chrysophyceae }\end{array}$ & - & - & 7 & & \\
\hline & & & & & 1738 & $4.8 \times 10^{6}$ \\
\hline \multirow[t]{7}{*}{24 Jan 1984} & $\begin{array}{l}\text { Nitzschia sp. } \\
\text { (chains) }\end{array}$ & 21 & 8 & - & & \\
\hline & $\begin{array}{l}\text { Nitzschia sp. } \\
\text { (solitary) }\end{array}$ & 36 & 11 & - & & \\
\hline & $\begin{array}{l}\text { Unid. flagellates } \\
\text { and monads }\end{array}$ & - & - & 3 & & \\
\hline & $\begin{array}{l}\text { Unid. large } \\
\text { flagellates and } \\
\text { Chrysophyceae }\end{array}$ & - & - & 5 & & \\
\hline & Gymnodinium sp. & - & - & 13 & & \\
\hline & $\begin{array}{l}\text { Coccolithus } \\
\text { pelagicus }\end{array}$ & - & - & 10 & & \\
\hline & & & & & 3506 & $2.3 \times 10^{5}$ \\
\hline
\end{tabular}

present (29 to $39 \mu \mathrm{m}$ long) that were absent in May. Silicoflagellates $28 \mu \mathrm{m}$ in diameter made up $2 \%$ of total cell volume, and coccoliths $4 \mu \mathrm{m}$ in diameter were common $\left(214\right.$ to $\left.286 \times \mathrm{ml}^{-1}\right)$. No intact coccolithophores were found in any sample preserved with Utermöhl's iodine.

The size frequency distributions show that in May the most frequently occurring cells were in the 10 to $20 \mu \mathrm{m}$ size class (Fig. 2). On 2 May the cell-volume frequency distribution was dominated by large cells in the 20 to $40 \mu \mathrm{m}$ size class, while on 6 May cell volume dominance had shifted to a smaller size class, 10 to 20 $\mu \mathrm{m}$ long (Fig. 2). These distributions do not include the length of tabular chains of pennate diatoms. In January the size frequency distribution showed the importance of small cells in the 0 to $5 \mu \mathrm{m}$ size class (Fig. 2). The cell-volume frequency distribution was more even than in May, with relatively equal volume in size classes from 5 to $40 \mu \mathrm{m}$.

\section{Contents of fecal pellets}

The contents of fecal pellets reflected the type and size of available food particles. The fecal pellets collected during the spring diatom bloom were dominated by pennate and centric diatoms, while those collected in January were dominated by coccoliths and dinoflagellates and contained fewer diatoms. 
Fecal pellets collected on 2 May contained a mixture of pennate and centric diatoms (Fig. 3). Predominant in the pellets were tabular chains of Nitzschia grunowii and $N$. cylindrus (Fig. 3a, b). Also ingested was the centric diatom Thalassiosira sp. Although Thalassiosira sp. was often broken into fragments (Fig. 3c, d),
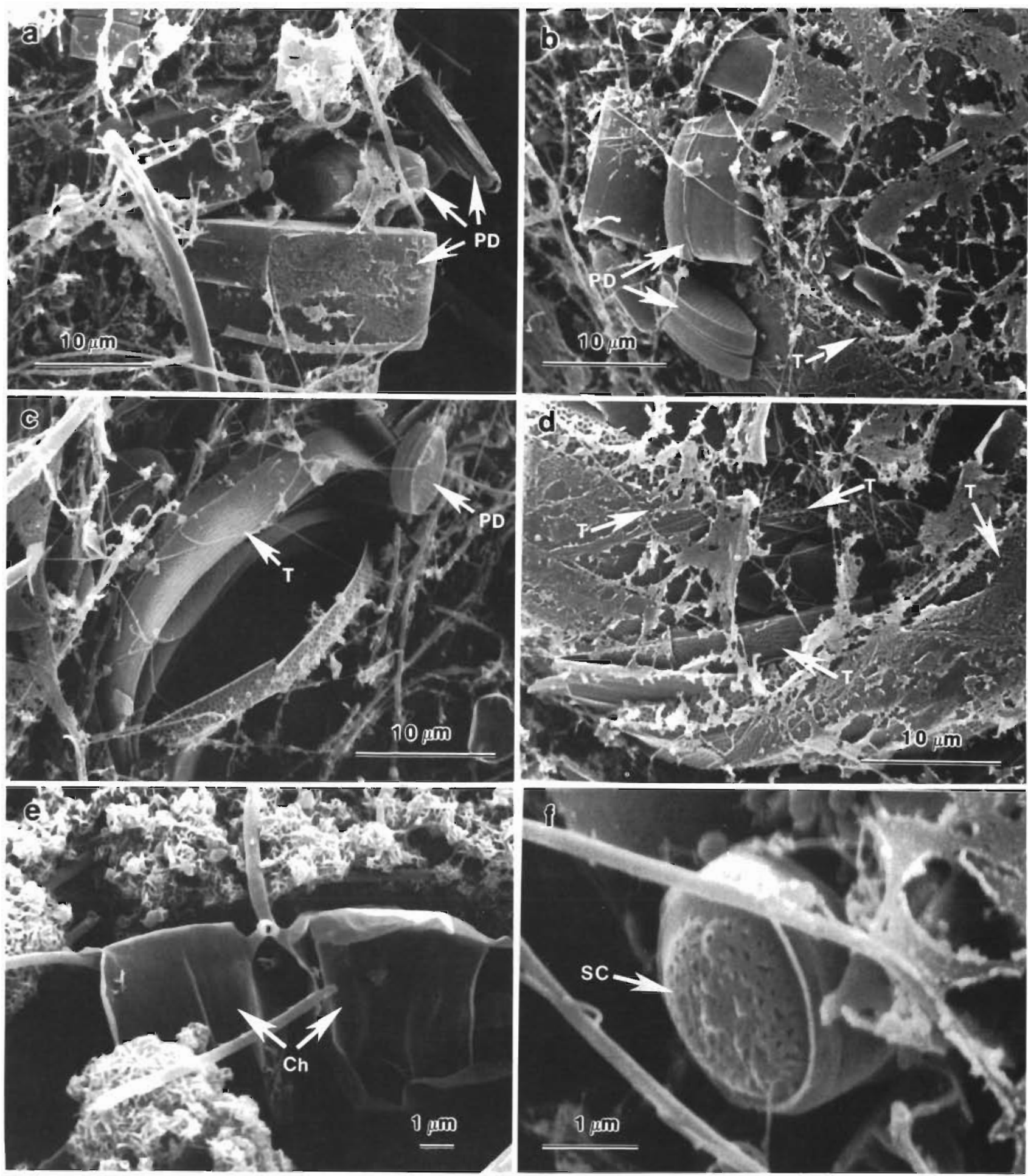

Fig. 3. Oikopleura vanhoeffeni. Contents of fecal pellets produced on 2 May 1983. Pellet contents reflect feeding in the field. (a) Pennate diatoms (PD), mostly Nitzschia grunowii; (b) pennate diatoms (PD), including $N$. grunowii, $N$. cylindrus and Thalassiosira sp. (T); (c) pennate diatom (PD) and a fragmented Thalassiosira sp. (T); (d) fragments of Thalassiosira sp. (T); (e) Chaetoceros socialis $(\mathrm{Ch}) ;(\mathrm{f})$ small centric diatom (SC). Note threads of pharyngeal mucus, particularly in (a) to (d) 
intact cells in pellets were about $30 \mu \mathrm{m}$ in diameter, similar to measurements made of available Thalassiosira sp. (Table 1). The unidentified centric diatoms were small, approximately 2 to $3 \mu \mathrm{m}$ in diameter (Fig. 3f). Spinous cells (Chaetoceros socialis Lauder) passed through the incurrent filters of these large houses (Fig. 3e). C. socialis in fecal pellets were 6 to $7 \mu \mathrm{m}$ wide, which agrees with measurements of available Chaetoceros sp. (Table 1). Few of the small pennate diatoms had crushed valves (Fig. $3 \mathrm{~b}$ ). There were small unicells in these fecal pellets (Fig. 3a, f). All cells were enmeshed in mucous fibers. These fibers were the remains of the pharyngeal mucous net.

Long tabular chains of pennate diatoms and large centric diatoms also were contained in fecal pellets collected on 6 May (Fig. 4 \& 5). Nitzschia cylindrus were small ( 6 to $10 \mu \mathrm{m}$ long) and intact (Fig. $4 \mathrm{a}, 5 \mathrm{a}$, b). There was a second type of tabular chain in these fecal pellets (Fig. 4b, c), with much larger cells ( $27 \mu \mathrm{m}$ long) than those of 2 May (Fig. 3). Also, a large, singular, pennate diatom was common on 6 May $(N$. seriata? Fig. 5c, d). There were several centric diatoms of both small and medium size that were fragmented (Fig. 5c), and Thalassiosira gravida Cleve $30 \mu \mathrm{m}$ in diameter that were intact (Fig. 5e). A few coccoliths were observed in May (Fig. 5d). There were no silico-flagellates or Rhizosolenia sp. in fecal pellets produced on 6 May.

Fecal pellets collected on 24 January were dominated by coccoliths and flagellates, reflecting the change in the composition of the phytoplankton community since the previous May (Fig. $6 \& 7$ ). Coccoliths, silicoflagellates, and dinoflagellates were relatively more important because of the decrease in the abundance of diatoms. Coccolithus pelagicus (Wallich) Schiller was about 8 to $10 \mu \mathrm{m}$ in diameter (Fig. 6c), and the individual coccoliths were $4.5 \mu \mathrm{m}$ in diameter (Fig. 6a, b). Large silicoflagellates - Distephanus speculum (Ehrenberg) Haeckel - passed through the incurrent filters (Fig. 6d). This specimen was $48 \mu \mathrm{m}$ from spine
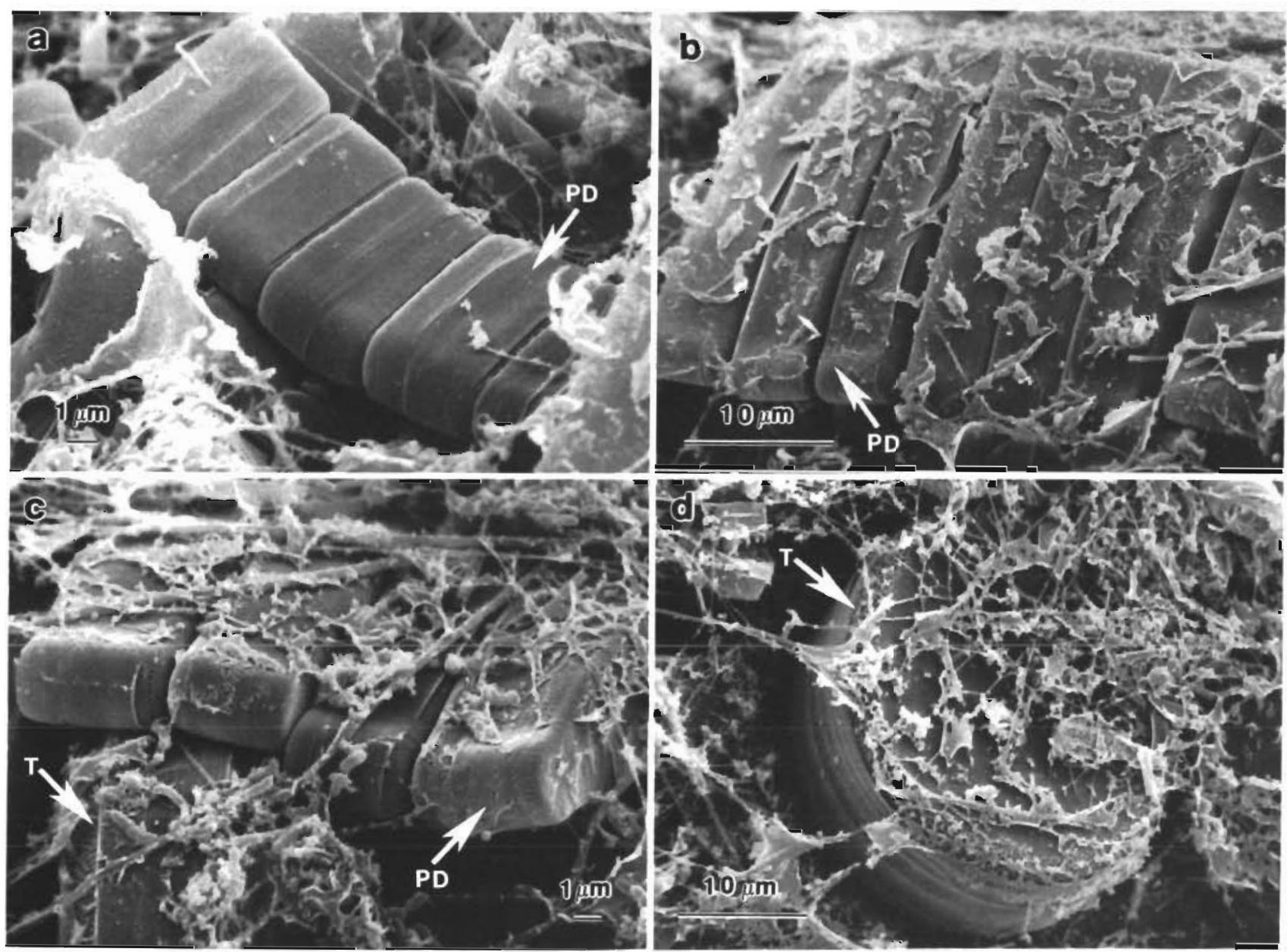

Fig. 4. Oikopleura vanhoeffeni. Contents of fecal pellets produced on 6 May 1983. Pellet contents reflect feeding in the field. (a) Chain of pennate diatoms (PD), probably Nitzschia cylindrus; (b) chain of unidentified pennate diatoms (PD); (c) chain of pennate diatoms (PD) and Thalassiosira sp. (T); (d) intact Thalassiosira sp. (T). Note threads of pharyngeal mucus, particularly in (d) 


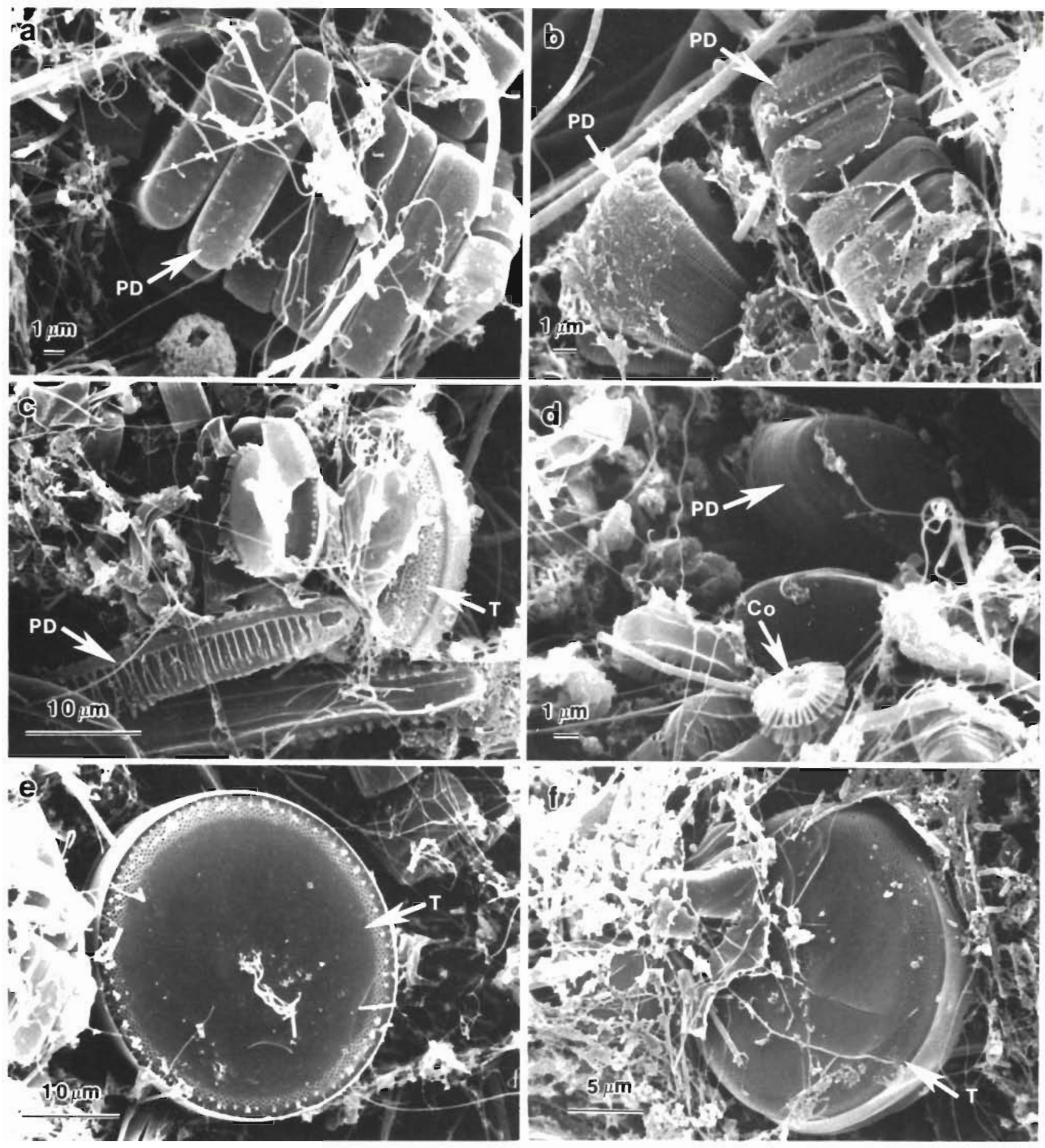

Fig. 5. Oikopleura vanhoeffeni. Contents of fecal pellets produced on 6 May 1983. Pellets were produced while the appendicularian was feeding in natural seawater in the laboratory within $12 \mathrm{~h}$ of collection. (a) Chain of pennate diatoms (PD) probably Nitzschia cylindrus; (b) pennate diatom (PD) (c) pennate diatom (PD) probably N. seriata and Thalassiosira sp. (T); (d) pennate diatom (PD) possibly N. grunowii and unidentified coccolith (Co); (e) and (f) Thalassiosira sp. (T)

tip to tip, and $24 \mu \mathrm{m}$ in diameter. There were many dinoflagellates in these fecal pellets, most of which were intact (Fig. 6e, f). The Prorocentrum sp. in Fig. 6e was about $10 \times 8 \mu \mathrm{m}$, and the Peridinium sp. in Fig. $6 \mathrm{f}$ was $35 \times 30 \mu \mathrm{m}$.
The pennate and centric diatoms that were present in fecal pellets on 24 January were different from those present the previous May (Fig. 7). There were small pennate diatoms 6 to $7 \mu \mathrm{m}$ long that formed short chains (Achnanthes sp.: Fig. 7a), and small, uniden- 

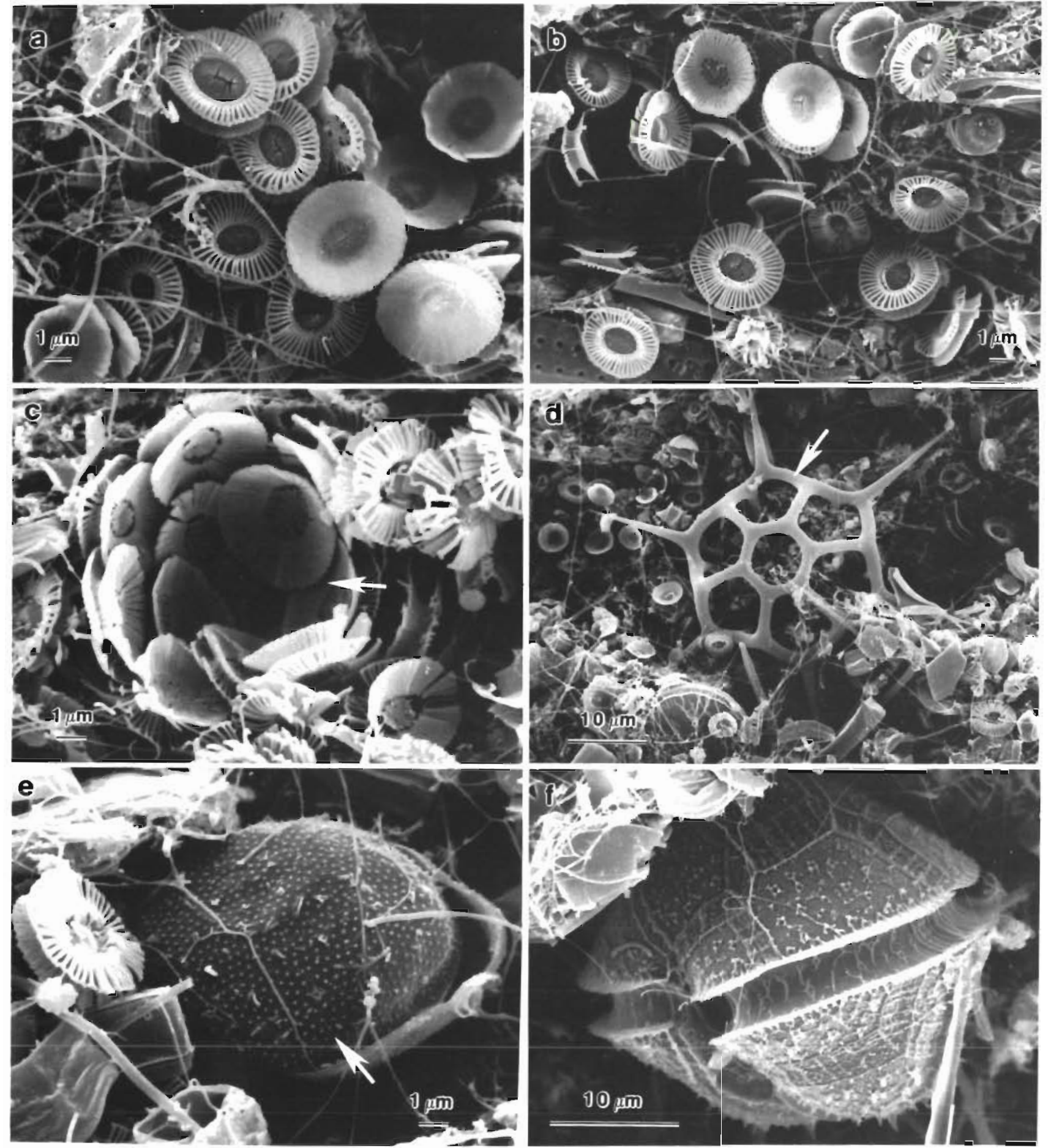

Fig. 6. Oikopleura vanhoeffeni. Contents of fecal pellets produced on 24 January 1984. Some pellets were produced by this individual in the field, and some were produced after feeding in natural sea water in the laboratory. (a) and (b) Coccoliths; (c) semi-intact coccolithophore (arrow) with the cytoplasm and a portion of the outer covering of coccoliths missing (view is from the interior of the cell to the interior surface of interlocking coccoliths on the back side of the cell); (d) silicoflagellate (arrow: Distephanus speculum v. regularis); (e) Prorocentrum sp. (arrow); (f) Peridinium sp.

tified centric diatoms 3 to $4 \mu \mathrm{m}$ in diameter (Fig. $7 \mathrm{e}, \mathrm{f}$ ). There was a large araphid diatom which was $35 \mu \mathrm{m}$ long (Fig. 7b, d). Also, there were small, solitary pen- nate diatoms that were about $8 \mu \mathrm{m}$ long (Nitzschiasp? Fig. 7c)

All fecal pellets from May and January were sur- 

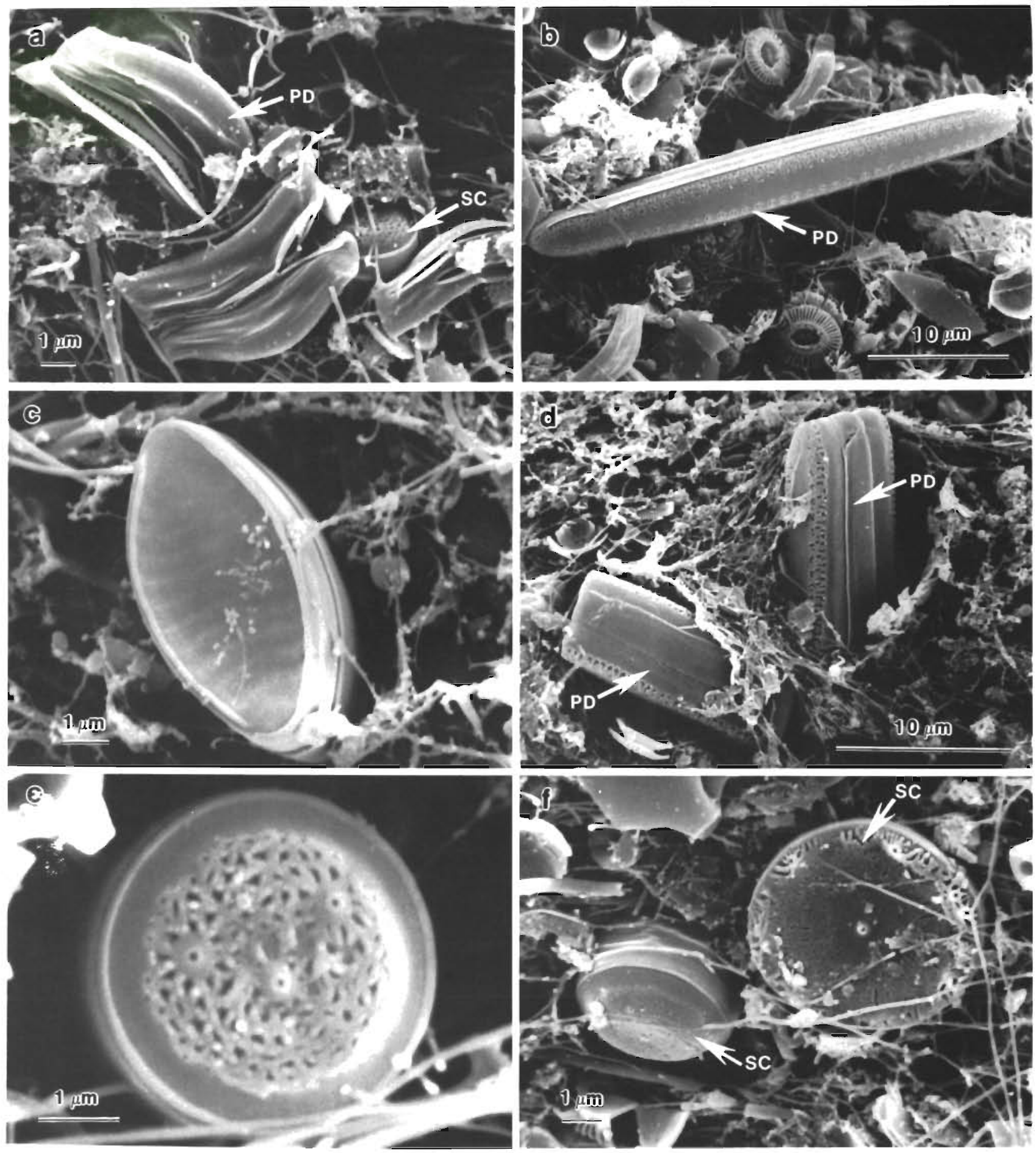

Fig. 7. Oikopleura vanhoeffeni. Contents of fecal pellets produced by the same individual as in Fig. 6. (a) Pennate diatoms (PD), probably Achnanthes sp., and a small centric diatom (SC); (b) pennate diatom (PD); (c) small pennate diatom; (d) pennate diatoms (PD); (e) small intact centric diatom $<4 \mu \mathrm{m}$ in diameter; (f) small centric diatoms (SC), $<6 \mu \mathrm{m}$ in diameter

rounded by a membrane (Fig. 8). After 24 to $36 \mathrm{~h}$ at room temperature parts of the membrane were broken and its surface was populated by rod-shaped bacteria forming colonies 6 to $10 \mu \mathrm{m}$ long (Fig. 8a).

\section{DISCUSSION}

Appendicularians seem to be true suspension feeders, collecting food particles by pumping water 

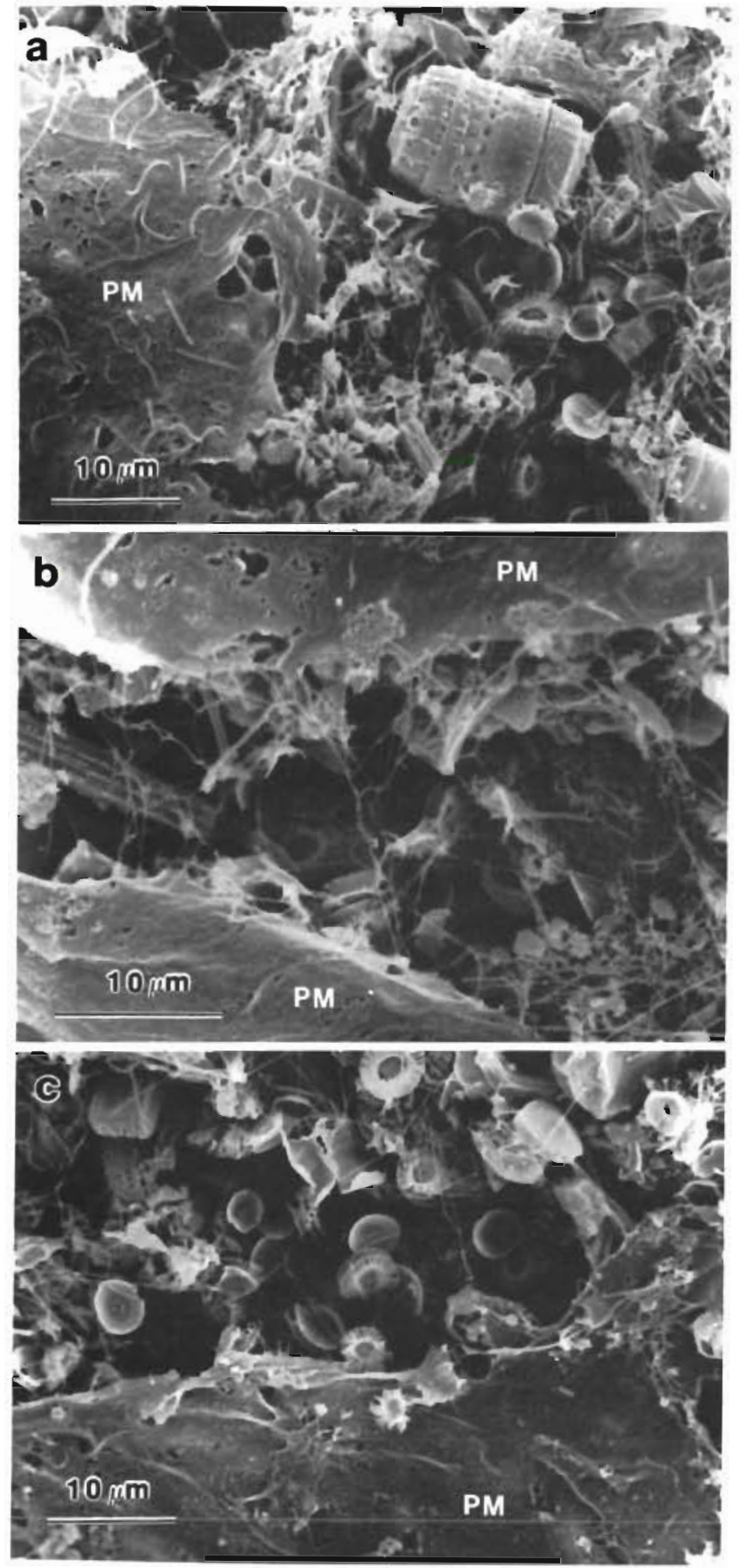

Fig. 8. Oikopleura vanhoeffeni. Contents of fecal pellets produced by the same individual as in Fig. 6 \& 7 . Note peritrophic membrane (PM) partially covering pellet contents composed primarily of coccoliths, threads of pharyngeal mucus, and diatoms

through a series of mucous filters. They do not positively select particles from a specific size range, but do exclude particles larger than the pore size of their incurrent filters (Alldredge 1975, 1977). Little is known of the physiology or ecology of the cold ocean appendicularian Oikopleura vanhoeffeni. We have examined the undigested contents of fecal pellets of $O$. vanhoeffeni to compare to the pore size of its incurrent filters, and to compare to available food particles.

The mean pore size of the incurrent filters of a subsample of juvenile and adult Oikopleura vanhoeffeni collected in May and January was $169 \pm 21 \times 88$ $\pm 9 \mu \mathrm{m}\left( \pm 95 \% \mathrm{CI}_{i} \mathbf{n}=20 ;\right.$ range $=112$ to $292 \times 50$ to $123 \mu \mathrm{m})$. The sizes of appendicularians and fecal pellets shown in Fig. 3 to 8 are summarized in Table 2. Although larger specimens had filters with larger pore widths, there was no statistically significant relation between pore width and trunk length or maturity stage. This is the largest incurrent filter pore width yet reported for any oikopleurid. In a study of 6 oikopleurid species, Alldredge (1977) found the incurrent filter pore width to vary from $13 \pm 5$ to $54 \pm 9 \mu \mathrm{m}$ ( \pm $\mathrm{SD}$ ). There was no statistically significant relationship between pore width and trunk length (Alldredge 1977).

The contents of fecal pellets of Oikopleura vanhoeffeni reflect the type and size frequency of available food particles. Alldredge (1975) found that the fecal pellets of 6 species of tropical oikopleurids contained predominantly bacteria, small unidentified particles, and naked flagellates, with secondary importance of dinoflagellates of moderate size and coccolithophores. Large dinoflagellates and diatoms occurred in much lower proportion than their occurrence in the environment, and particles $>6 \mu \mathrm{m}$ in size were excluded by all species to some extent. We found that the largest particles in the fecal pellets of $O$. vanhoeffeni were smaller than the mean pore size of the incurrent filters. We also established that fecal pellet contents were dominated by medium sized diatoms and intact tabular chains of small pennate diatoms. Extremely long pennate diatoms, such as Rhizosolenia sp. (300 to $400 \mu \mathrm{m}$ long), were ingested infrequently.

Irregularly shaped or spinous cells have been reported not to be consumed by oikopleurids (Lohmann 1909, Alldredge 1975). Lohmann (1909) found the gut contents of Oikopleura albicans to be colorless and $<3 \mu \mathrm{m}$ in diameter, and to include skeletal parts of Peridineae, Diatomeae, and Coccolithophoridae. The largest particle Lohmann found in the gut was $20 \mu \mathrm{m}$ in diameter, while the largest particle found by Zaika (1972) in the gut of $O$. dioica was $40 \mu \mathrm{m}$ in diameter. Lohmann (1909) did not find the remains of the large and/or chain-forming diatoms, Chaetoceros sp., Skeletonema sp., Bacteriastrum sp., and Rhizosolenia sp. in fecal pellets. However, Zaika (1972) found various dinoflagellates and diatoms in the gut of $O$. dioica, including Peridinium sp., Thalassiosira sp., and Distephanus sp. We observed Chaetoceros socialis with spines attached, and long tabular chains of pennate diatoms in the fecal pellets of $O$. vanhoef- 
Table 2. Oikopleura vanhoeffeni. Body size and fecal-pellet size in Fig. 3 to 8

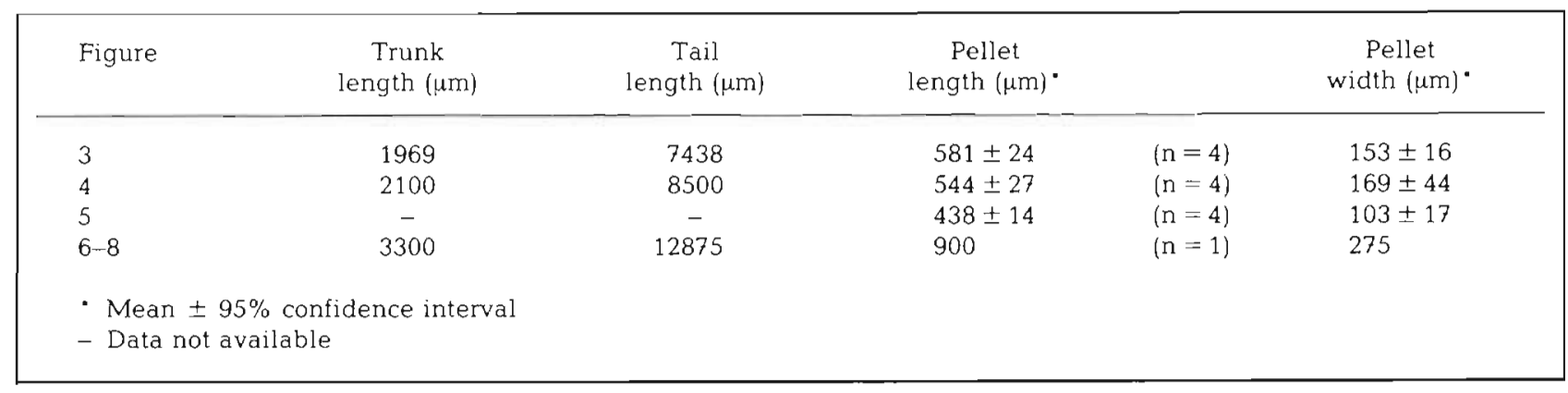

feni (Fig. 3 to 7). Thus, O. vanhoeffeni could have a major impact on large, armored cells during the spring diatom bloom in cold ocean waters. The largest single particle we observed in fecal pellets of $O$. vanhoeffeni was the silicoflagellate Distephanus speculum, which was $48 \mu \mathrm{m}$ from spine tip to tip. The longest tabular chains of pennate diatoms in fecal pellets were $>40 \mu \mathrm{m}$ long.

The nutritional value of diatoms and thecate dinoflagellates to pelagic tunicates has not been investigated. The frequency of intact cells in the fecal pellets of Oikopleura vanhoeffeni was remarkable (Fig. 3 to 8), but was not surprising, since oikopleurids have no chewing or grinding mouthparts. As Alldredge (1975) found, coccolith plates appeared to be intact and to have undergone no solution. Examination of fecal pellets from salps using transmission electron microscopy have shown many intact diatoms with no cytoplasm, indicating a high frequency of digestion and leaching of cell contents (Silver \& Bruland 1981). Because of similarity in feeding mechanism and in the type of food consumed by salps and appendicularians, we suspect that $O$. vanhoeffeni also extracts diatom cytoplasm from intact cells. However, the digestive enzymes of appendicularians have not been investigated.

The fecal pellets of Oikopleura vanhoeffeni were surrounded by a 'membrane' (Fig. 8), which we assume is analogous in function to the peritrophic membrane which surrounds the fecal pellets of planktonic copepods (Honjo \& Roman 1978, Turner \& Ferrante 1979). This membrane was continuous in freshly produced fecal pellets, but was rapidly decomposed by bacteria when the pellets were incubated at room temperature (Fig. 8). Apparently the fecal pellets of other pelagic tunicates are surrounded by a membrane (Silver \& Alldredge 1981, Madin 1982), although these membranes have not been described.

In January, the fecal pellets of Oikopleura vanhoeffeni contained many coccoliths (Coccolithus pelagicus: Fig. 6 \& 7). Because of the high clearance rates of $O$. vanhoeffeni (up to $15 \mathrm{ld}^{-1}$; Deibel unpubl.), and the high fecal pellet production rates $\left(3\right.$ to $4 \mathrm{~h}^{-1}$ at $2{ }^{\circ} \mathrm{C}$ :
Deibel unpubl.), a single $O$. vanhoeffeni can capture and package great numbers of coccolithophores into fecal pellets each day. Since $O$. vanhoeffeni is usually present and is often dominant in Newfoundland waters (up to $450 \mathrm{~m}^{-3}$; Davis 1982), its populations may have a significant impact on the transport of calcite to the benthos. This role has been proposed for other pelagic tunicates (Gowing \& Silver 1983).

It is likely that the incurrent filters of Oikopleura vanhoeffeni will exclude few of the common phytoplankton of Newfoundland coastal waters. The pore width of the incurrent filters was greater than the minimum dimension (i.e. diameter or width) of all of the available phytoplankton we identified (Table 1). However, the spatial orientation of the largest cells or tabular chains is probably important if they are to pass through the incurrent filters. We have investigated the undigested contents of fecal pellets that were detected by SEM. It is likely that unarmored cells not detected by SEM comprise a large portion of fecal pellet contents. Our results indicate that because of the large pore size of the incurrent filters of $O$. vanhoeffeni, both large armored cells and small unarmored cells should be included in future considerations of the diet.

Acknowledgements. We thank Gordon Chaisson (divemaster), Bob Guest, Art Barnes, Jim Woolridge, and Jerry Ennis of the Marine Sciences Research Laboratory Diving Unit for assisting D. D. with the collection of Oikopleura vanhoeffeni. Malcolm Foy, LGL Limited, St. John's, helped with the identification of phytoplankton in the inverted microscope samples and on the SEM plates. We thank Chuck Bland for access to the electron microscopy facilities of East Carolina University, and Tim Charles for assistance with SEM specimen preparation. Electron microscopy was performed while J. T. T. was on leave from Southeastern Massachusetts University, on an Intergovernmental Personnel Assignment with the National Marine Fisheries Service, NOAA, Beaufort, North Carolina, USA. This work was supported by a President's General Grant from Memorial University of Newfoundland and by an Operating Grant from the Natural Sciences and Engineering Research Council of Canada. This manuscript is Marine Sciences Research Laboratory Contribution Number 599, and Newfoundland Institute for Cold Ocean Science Contribution Number 75 . 


\section{LITERATURE CITED}

Alldredge, A. L. (1975). Quantitative natural history and ecology of appendicularians and discarded appendicularian houses. Ph. D. thesis, Univ. Calif., Davis

Alldredge, A. L. (1977). House morphology and mechanisms of feeding in the Oikopleuridae (Tunicata, Appendicularia). J. Zool. Lond. 181: 175-188

Alldredge, A. L. (1981). The impact of appendicularian grazing on natural food concentrations in situ. Limnol. Oceanogr. 26: 247-257

Alldredge, A. L., Madin, L. P. (1982). Pelagic tunicates: unique herbivores in the marine plankton. Bioscience 32 (8): 655-663

Davis, C. C. (1982). A preliminary quantitative study of the zooplankton from Conception Bay, Insular Newfoundland Canada. Int. Revue ges. Hydrobiol. 67 (5): 713-747

Galt, C. P. (1972). Development of Oikopleura dioica (Urochordata: Larvacea): ontogeny of behavior and of organ systems related to construction and use of the house. Ph. D. thesis, Univ. of Washington, Seattle

Gowing, M. M., Silver, M. W. (1983). Origins and microenvironments of bacteria mediating fecal pellet decomposition in the sea. Mar. Biol. 73: 7-16

Honjo, S., Roman, M. R. (1978). Marine copepod fecal pellets: production, preservation and sedimentation. J. mar. Res. 36 (1): 45-57

Jansa, J. (1977). Estudio preliminar del contenido en pigmentos fotosintéticos en el tubo digestivo de apendicularias y salpas. Boln. Inst. esp. Oceanogr. 228: 7-29

Kendaris, T. A. (1980). Physical and biological oceanographic observations in Logy Bay, Newfoundland: April-September 1979. Can. Ms. Report of Fish. and Aquatic Sci. Dept. Fish. Oceans, St. John's, 1569; 1-60

Lohmann, H. (1909). Die Gehäuse und Gallertblasen der Appendicularien und ihre Bedeutung für die Erforschung des Lebens im Meer. Verh. dt. zool. Ges. 19: 200-239
Lund, J. W. G., Kipling, C., Le Cren, E. D. (1958). The inverted microscope method of estimating algal numbers and the statistical basis of estimations of counting. Hydrobiologia 11: $143-170$

Madin, L. P. (1982). Production, composition and sedimentation of salp fecal pellets in oceanic waters. Mar. Biol. 67 $39-47$

Silver, M. W., Alldredge, A. L. (1981). Bathypelagic marine snow: deep-sea algal and detrital community. J. mar. Res 39: $501-530$

Silver, M. W., Bruland, K. W. (1981). Differential feeding and fecal pellet composition of salps and pteropods, and the possible origin of the deep-sea flora and olive-green 'cells' Mar. Biol. 62: 263-273

Turner, J. T (1984a). Zooplankton feeding ecology: contents of fecal pellets of the copepods Eucalanus pileatus and Paracalanus quasimodo from continental shelf waters of the Gulf of Mexico. Mar. Ecol. Prog. Ser. 15: 27-46

Turner, J. T (1984b). Zooplankton feeding ecology: contents of fecal pellets of the copepods Temora turbinata and $T$ stylifera from continental shelf and slope near the mouth of the Mississippi River. Mar. Biol. 82: 73-83

Turner, J. T (1984C). Zooplankton feeding ecology: contents of fecal pellets of the copepods Acartia tonsa and Labidocera aestiva from continental shelf waters near the mouth of the Mississippi River P.S.Z.N. Mar Ecol. 5: 265-282

Turner, J. T., Ferrante, J. G. (1979). Zooplankton fecal pellets in aquatic ecosystemts. Bioscience 29: 670-677

Udvardy, M. D. F. (1954). Distribution of appendicularians in relation to the Strait of Belle Isle. J. Fish. Res. Bd Can. 11 (4): $431-453$

Utermöhl, H. (1958). Zur Vervolkommung der quantitativen Phytoplanktonmethodik. Mitt. int. Verein. theor angew. Limnol. 9: 1-38

Zaika, V E. (1972). Specific production of aquatic invertebrates. Naukova Dumka, Kiev 